Journal of Teacher Education for Sustainability, vol. 17, no. 1, pp. 86-98, 2015

\title{
Communication Skills Training in Trainee Primary School Teachers in Spain
}

\author{
José Luis Gallego Ortega and Antonio Rodríguez Fuentes \\ University of Granada, Spain
}

\begin{abstract}
Research on teacher training often focuses on learners' perceptions of that training. The focus of this paper, which uses a research-to-practice approach, is instead on the views of the trainers. It evaluates the perceptions of university lecturers teaching classes as part of primary teachers' training degrees and assesses their views of the communication skills developed by their students to be used in their future careers. The study uses a 17 -item ad-hoc questionnaire, completed by 152 lecturers from the University of Granada. Descriptive and inferential analyses are then carried out on the data collected using SPSS. The analysis results show how important lecturers believe it is for trainee teachers to develop communication skills, which they often lack. Although lecturers believe communication skills are very important, they also think that they are not developed as much as they should be in their classes, so trainee teachers cannot communicate as effectively as they should.
\end{abstract}

Keywords: classroom communication skills, communication in teaching, developing communication skills, education communication, primary teacher training

Communication is an interpretative process through which agents interact, responding and creating messages sent via a conduit using a specific code. Each communicative act is unique and is an unrepeatable combination of specific individuals, intentions, places, moments and circumstances. When this act takes place in schools and classrooms, it is known, in the Spanish-language literature at least, as educational communication, communicative pedagogy (Kaplún, 2004), educommunication (Sánchez Cerezo, 1991) or pedagogical communication skills (Cruzata \& Salazar, 2012). The interaction is usually between teachers and students, and its aim is primarily educational, although communication also takes place between teachers and institutions, between two or more teachers, and so on.

The quality of teaching depends, in part, on the quality of communication in the classroom, so researchers have recently become interested in how to ensure that communication is as effective as it can be. Of all the skills that a teacher must have, communication skills are particularly important. Although interest in the topic is relatively recent, the importance of communication has led to numerous studies on teachers' communica- 
tion skills which can be used to help guide the initial teacher training process (Bolívar \& Domingo, 2004; Barrón, 1989; Camacho \& Sáenz, 2000; Camacho, Martínez, \& Mendías, 1999; Cascante, 2004; Perrenoud, 2007; Castellá, Comelles, Cross, \& Vilà, 2007). In all of these studies, communication skills are seen as an essential part of the teacher's professional repertoire. Some studies have found that teachers have problems communicating, either because they are unaware of the keys to effective communication or because of other factors associated with their own personalities or methods of communicating. The receiving and understanding of messages can also be disrupted by the behaviour of the speaker and listener as well as by external factors.

Although the importance of communication is widely acknowledged and shortcomings have been detected in this area most teachers do not receive specific training on classroom communication. It is only recently that innovative new techniques have started to be incorporated into continuing teacher training programmes. This appears to be true of most countries (Kaplún, 2004), which are interested for incorporating the communicational competences into the teaching training in the current society of the knowledge, known as the society of the information and communication. Obviously, the value of this research is limited from the geographical context in which the study was done, although it may serve as an example and encourage research studies in other contexts. It is also surprising that although there are plenty of theoretical studies on what communication skills consist of and how they can be developed. There are few empirical studies on the real need for them for practising teachers, as part of their continuing education or professional development. There are even fewer studies on communication skills during initial teacher training.

The development of communication skills in primary teacher training is exceedingly important (National Agency for Quality Assessment [ANECA], 2004), so this paper focuses on that area. The overall aim is to assess how well-developed trainee teachers' communication skills are and how university lecturers try to develop those skills in their students. More specifically, the aim is to evaluate lecturers' perceptions of the communication skills of their students - future primary school teachers - and to what degree the different communication sub-skills (communicating academic and pedagogical content, listening, communicating in the classroom, attending meetings and acting as a tutor) are developed throughout the degree.

The objectives of this study are therefore to:

- find out how important university lecturers feel it is to develop communication skills in trainee primary teachers;

- find out how much work lecturers do during their classes to help to develop communication skills in their students (primary teachers in training);

- assess the communication skills of trainee primary teachers based on the perception of their lecturers;

- evaluate the relationships between the three previous variables in order to detect any shortcomings in trainee teachers' acquisition of communication skills. 


\section{Method}

This descriptive study uses a quantitative research method. This approach was selected because it was deemed to be the most appropriate for the hypothesis and objectives previously stated as it provides an overview of the approach to teaching communication skills in trainee primary teachers' and lecturers' perceptions of those skills. The complexity of the quantitative approach can vary, ranging from simple reports of frequency (descriptive studies) to studies that analyse relationships or links (analyses of correlations or contingencies). This study uses both methods, making use of all of the analytical methods available to interpret the phenomenon studied.

Given the objectives and focus of this paper, the survey research (McMillan \& Schumacher, 2005) approach was selected for use here because of its versatility, efficiency, generality, suitability, reliability, comparison and applicability (Cohen \& Manion, 2002; Schutt, 2001). A cross-sectional design was chosen, as it is the most suitable and frequent approach used in survey research.

The specific data collection technique used was the questionnaire, a frequently used approach (Cea, 2002) as this method makes it possible to obtain information from the research population about the variables studied in a systematic and organised way (McMillan \& Schumacher 2005). It was essential for the questionnaire to include specific questions about the research objectives so that those objectives could be met using information about the real situation of the research population. Questionnaire surveys gather data at a particular moment with the aim of describing existing conditions, identifying norms/patterns with which to compare these existing conditions and determining relationships between specific events (Cohen \& Manion, 2002).

A review was carried out incorporating a number of standardised questionnaires used in other analyses, and an ad hoc questionnaire was selected. This questionnaire was validated using the panel of experts and triangulation method (Fox, 1987). It is a 17-item multiple choice questionnaire using a 5-point Likert scale ( $1=$ not at all/never; 2 = a little/not enough; 3 = somewhat/enough; 4 = quite a lot/a lot; 5 = always/very much). The questionnaire included questions on each of the different sub-skills of communication skills. Respondents were asked if they worked on each sub-skill in their classes or not, if they believed that they should have and to what extent they believed their students achieved that sub-skill. Each sub-skill was allocated one section of the questionnaire, resulting in a total of five sections, one for each of the five communication sub-skills that future teachers must have as a speaker, a listener, a teacher, a meeting attendee and a tutor (Camacho \& Sáenz, 2000; Camacho et al., 1999; Sanz, 2005).

The study group was made up of lecturers in the primary teacher training course at the University of Granada (Spain). Tagliacarne's equation (1968) was used to calculate the sample group size required for reliable statistically significant findings in finite populations. The sample used was large enough to be statistically significant as it consisted of more than half of the reference population, a total of 152 teachers.

Once the data had been collected, they were analysed using quantitative techniques suited to the demands of the statistical model and research objectives, using different statistical and descriptive approaches. The data were analysed using SPSS 14.0. Two types of analysis were carried out: a descriptive analysis and a contingency analysis. 
- The descriptive analysis, quantifying tendencies, was carried to calculate for each variable in order to estimate its distribution, with the aim of providing an overview of the sample group based on the distribution of the variables studied. Central tendency was measured using means, medians and modes. The variance and the standard deviation were calculated to provide data about frequency distribution. Partial, cumulative and total percentages were calculated for each sub-aspect or dependent variable. Frequencies were also calculated.

- The contingency analysis was used to summarise the relationships between the categorical variables (Sánchez Carrión, 1989). In this case, the general importance of communication skills for teachers and the three aspects were assessed: need to work on communication skills during primary teacher training courses; work done on this area in each subject and/or by each lecturer and progress made by students. Chi-squared distribution was used to determine if the relationships between these variables were statistically significant. Values lower than 0.001 were deemed statistically significant.

\section{Results}

When asked about the general importance of communication skills for teaching, $91.2 \%$ of the lecturers surveyed replied that they are very important (score 5 on the Likert scale, see Table 1). None of the lecturers answered that communication skills were not at all important ( 1 on the scale). As the frequencies and cumulative percentages in Table 1 show (the cumulative percentages for answers 2, 3 and 4 on the scale amount to less than $8 \%$ ), none of the other answers on the 5 -point scale were representative or significant.

Table 1

Importance of Communication Skills in Teaching

\begin{tabular}{lccccc}
\hline & & Frequency & Percentage & $\%$ valid & $\%$ accumulated \\
\hline \multirow{4}{*}{ Valid } & 2.00 & 2 & $1,3 \%$ & $1,3 \%$ & $1.3 \%$ \\
\cline { 2 - 6 } & 3.00 & 2 & $1.3 \%$ & $1,3 \%$ & $2.6 \%$ \\
\cline { 2 - 6 } & 4.00 & 8 & $5.3 \%$ & $5,3 \%$ & $7.9 \%$ \\
\cline { 2 - 6 } & 5.00 & 140 & $91.2 \%$ & $91.2 \%$ & $100 \%$ \\
\hline Total & \multicolumn{7}{c}{$100 \%$} & $100 \%$ & \\
\hline
\end{tabular}

The following sections outline the descriptive data along with the contingencies for each of the three aspects studied. The significant contingencies were analysed by crosstabulating the lecturers' responses in order to provide a more comprehensive overview of their views about communication skills. The most significant findings resulted from cross-tabulating their responses about the importance of communication skills with their responses, by sub-skills, on whether that sub-skill should be worked on, whether it is worked on in class and the lecturers' perceived level of acquisition of that sub-skill by students, for the five sections of the questionnaire (a speaker, a listener, a teacher, a meeting attendee, a tutor). 


\section{Lecturers' Views on the Need to Work on Communication Skills}

It is clear that most of the lecturers believe that it is very important to include work on communication skills in primary teacher training (Table 2). The highest frequencies are for value 5 on the 5 -point scale, with an overall mean of more than $70 \%$. The means for each communication sub-skill are all higher than the overall mean, with the exception of the need for skills for taking part in meetings, which scored a little over $60 \%$ with a weighted average of 4.5 (still statistically significant) and a slightly lower variance and a standard deviation than the other types of communication. The overall weighted mean for this question is 4.6. The mode and median for all items is 5 .

Table 2

Need to Work on Communication Skills in Primary Teacher Training Courses

\begin{tabular}{|c|c|c|c|c|c|c|c|c|c|c|c|c|c|c|}
\hline \multirow[b]{2}{*}{ Value/role } & \multicolumn{2}{|c|}{$\begin{array}{c}\text { Nothing } \\
(1)\end{array}$} & \multicolumn{2}{|c|}{$\begin{array}{c}\text { Little } \\
(2)\end{array}$} & \multicolumn{2}{|c|}{$\begin{array}{c}\text { Normal } \\
(3)\end{array}$} & \multicolumn{2}{|c|}{$\begin{array}{l}\text { Quite } \\
(4)\end{array}$} & \multicolumn{2}{|c|}{$\begin{array}{c}\text { Always } \\
(5)\end{array}$} & \multirow[b]{2}{*}{$\frac{\ddot{8}}{\sum^{0}}$} & \multirow[b]{2}{*}{$\sum_{\Sigma}^{\Xi}$} & \multirow[b]{2}{*}{ 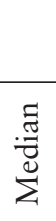 } & \multirow[b]{2}{*}{ 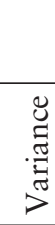 } \\
\hline & $\mathrm{n}$ & $\%$ & $\mathrm{n}$ & $\%$ & $\mathrm{n}$ & $\%$ & $\mathrm{n}$ & $\%$ & $\mathrm{n}$ & $\%$ & & & & \\
\hline Speaker & 0 & 0 & 0 & 0 & 4 & 2.6 & 31 & 19.7 & 117 & 76.3 & 5 & 4.7 & 5 & 0.6 \\
\hline Listener & 0 & 0 & 4 & 2.6 & 4 & 2 & 39 & 25.6 & 105 & & 5 & 4.6 & 5 & 0.5 \\
\hline Teacher & 0 & 0 & 2 & 1.3 & 12 & 7.9 & 26 & 17.1 & 112 & 73.7 & 5 & 4. & 5 & 0.7 \\
\hline Attender & 0 & 0 & 10 & 6.6 & 0 & 0 & 50 & 32.9 & 92 & 60.5 & 5 & 4.5 & 5 & 0.4 \\
\hline Tutor & 0 & 0 & 4 & 2.6 & 2 & 1.3 & 26 & 17.1 & 120 & 78.9 & 5 & 4.7 & 5 & 0.6 \\
\hline Mean & 0 & 0 & 4 & 2.6 & 4.4 & 2.9 & 34.4 & 22.6 & 109.2 & 71.8 & 5 & 4.6 & 5 & 0.5 \\
\hline
\end{tabular}

A contingency analysis (Table 3) was carried out, grouping the percentages into 2 categories (high and low importance of communication skills), revealing that the lecturers are quite aware of the need to work on communication skills: $95.2 \%$ consider it to be important, and just a small minority group $(4.8 \%)$ believe that it is not necessary to do any significant work on these skills.

Table 3

Variable Cross Tabulation: Need to Work on Communication Skills and Importance of Communication

\begin{tabular}{|c|c|c|c|c|}
\hline \multirow{2}{*}{\multicolumn{2}{|c|}{$\begin{array}{l}\text { Need to work } \\
\text { Importance }\end{array}$}} & \multicolumn{2}{|c|}{ Work studies } & \multirow{2}{*}{ Total } \\
\hline & & 2 & 4 & \\
\hline 2 & $\begin{array}{l}\% \text { within } \mathrm{V}_{2} \\
\% \text { of total }\end{array}$ & $\begin{array}{l}20 \% \\
4.8 \%\end{array}$ & $\begin{array}{c}80 \% \\
19.3 \%\end{array}$ & $23.8 \%$ \\
\hline 3 & $\begin{array}{l}\text { \% within } \mathrm{V}_{2} \\
\% \text { ofl total }\end{array}$ & $\begin{array}{l}0 \% \\
0 \% \\
\end{array}$ & $\begin{array}{l}100 \% \\
23.3 \% \\
\end{array}$ & $23.8 \%$ \\
\hline 4 & $\begin{array}{l}\% \text { within } \mathrm{V}_{2} \\
\% \text { of total }\end{array}$ & $\begin{array}{l}0 \% \\
0 \%\end{array}$ & $\begin{array}{l}100 \% \\
52.4 \%\end{array}$ & $52.4 \%$ \\
\hline Total & $\%$ within $\mathrm{V}_{2}$ & $4.8 \%$ & $95.2 \%$ & $100 \%$ \\
\hline
\end{tabular}

Examining the relationship between this and how important the lecturers feel communication skills are, it becomes apparent that only respondents in the second group 
(those who believe that the skills do not need to be worked on in class) believe that the skills are not very important. As a result, around 20\% responded that the skills should only be worked on a little or not much. However, $19.3 \%$ of the same group, like the vast majority of their colleagues, believe that considerable work should be done on communication skills.

\section{Lecturers' Work on Communication Skills during Classes}

The lecturers believe that training on communication skills for teaching is satisfactory ( 3 on the Likert scale) in the classes that they teach. In fact, the overall score for the different sub-skills of communication is 3 , with similar scores for the responses on either side of the middle ( 1 and $5 / 2$ and 4 ), as Table 4 shows. The overall mode and median for the different sub-skills are also both 3 , with means around the same value. However, the remaining scores are not quite as equidistant from the middle score in this case as the mean scores for the first 3 sub-skills in Table 4 (speaker, listener and teacher) are higher than 3 (3.1, 3.2 and 3.2 respectively). In other words, the frequencies of scores 4 and 5 are considerably higher than those for 1 and 2 respectively. However, for the final two skills, the opposite happens: the means are lower than the middle value of 3 (2.9 and 2.7 respectively), and the frequencies of scores 1 and 2 are much higher than those for 4 and 5 respectively. Furthermore, the means are not the only noteworthy results. As Table 4 shows, the variance (1.2) and standard deviation (1.1) of the final sub-skill (a tutor) are quite different from the overall variance and standard deviation (0.8 and 0.9 respectively). This indicates a greater data spread.

Table 4

Amount of Work on Communication Skills by Lecturers

\begin{tabular}{|c|c|c|c|c|c|c|c|c|c|c|c|c|c|c|}
\hline \multirow[b]{2}{*}{ Value/role } & \multicolumn{2}{|c|}{$\begin{array}{c}\text { Nothing } \\
(1)\end{array}$} & \multicolumn{2}{|c|}{$\begin{array}{l}\text { Little } \\
(2)\end{array}$} & \multicolumn{2}{|c|}{$\begin{array}{c}\text { Normal } \\
(3)\end{array}$} & \multicolumn{2}{|c|}{$\begin{array}{l}\text { Quite } \\
(4)\end{array}$} & \multicolumn{2}{|c|}{$\begin{array}{c}\text { Always } \\
(5)\end{array}$} & \multirow[b]{2}{*}{$\frac{0}{\frac{0}{0}}$} & \multirow[b]{2}{*}{ 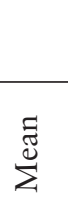 } & \multirow[b]{2}{*}{$\frac{\Xi}{\stackrel{\Xi}{0}}$} & \multirow[b]{2}{*}{ 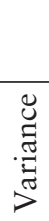 } \\
\hline & $\mathrm{n}$ & $\%$ & $\mathrm{n}$ & $\%$ & $\mathrm{n}$ & $\%$ & $\mathrm{n}$ & $\%$ & $\mathrm{n}$ & $\%$ & & & & \\
\hline & 0 & 0 & 40 & & 66 & & & & 4 & 2.6 & 3 & 3.1 & 3 & 0.4 \\
\hline Listener & 0 & 0 & 26 & 17.1 & 76 & 50 & 42 & 27.6 & 8 & 5.3 & 3 & 3.2 & 3 & 0.7 \\
\hline Teacher & 2 & 1.3 & 36 & 23.7 & 68 & 44.7 & 34 & 22.4 & 12 & 7.9 & 3 & 3.1 & 3 & 0.9 \\
\hline Attender & 10 & 6.6 & 38 & 25 & 66 & 43.4 & 34 & 22.4 & 4 & 2.6 & 3 & 2.9 & 3 & 0.8 \\
\hline Tutor & 22 & 14.5 & 44 & 28.9 & 50 & 32.9 & 28 & 18.4 & 8 & 5.3 & 3 & 2.7 & 3 & 1.2 \\
\hline Mean & 8.8 & 5.7 & 36.8 & 23.9 & 65.2 & 42.3 & 36 & 23.4 & 7.2 & 4.7 & 3 & 3 & 3 & 0.8 \\
\hline
\end{tabular}

According to the contingency analysis (Table 5), 53.3\% of the lecturers believe that they work on these skills enough, $40 \%$ of the respondents - work on them little or not enough and $6.7 \%$ of the respondents say that they do not work on them at all. $16.7 \%$ of the respondents believe that working on the skills is unimportant, $16.7 \%$ of the respondents believe that it is quite important and $66.7 \%$ of the respondents say that it is important. None of the other responses on the scale were used. 
Looking at this another way, 93.3\% of the lecturers say that they work on communication skills between a little and enough, but they are the same lecturers who believe the skills are more important. Those who believe working on the skills is less important are obviously more likely to answer that they do not work on those skills at all. The data are therefore very similar to the descriptive data in the previous table.

Table 5

Variable Cross Tabulation: Work on Communication Skills in Classes and Importance of Communication

\begin{tabular}{clcccc}
\hline \multirow{2}{*}{$\begin{array}{c}\text { Classroom work } \\
\text { Importance }\end{array}$} & \multicolumn{3}{c}{ Classroom work } & \multirow{2}{*}{ Total } \\
\cline { 2 - 4 } 2 & $\%$ within $\mathrm{V}_{2}$ & $20 \%$ & $20.0 \%$ & $60 \%$ & \\
\hline \multirow{2}{*}{2} & $\%$ of total & $3.3 \%$ & $3.3 \%$ & $10 \%$ & $16.7 \%$ \\
\hline \multirow{2}{*}{3} & $\%$ within $\mathrm{V}_{2}$ & $0 \%$ & $40 \%$ & $60 \%$ & \\
& $\%$ of total & $0 \%$ & $6.7 \%$ & $10 \%$ & $16.7 \%$ \\
\hline \multirow{2}{*}{4} & $\%$ within $\mathrm{V}_{2}$ & $5 \%$ & $45 \%$ & $50 \%$ & \multirow{2}{*}{$66.7 \%$} \\
\hline \multirow{2}{*}{ Total } & $\%$ of total & $3.3 \%$ & $30 \%$ & $33.3 \%$ & $100 \%$ \\
\hline
\end{tabular}

\section{Lecturers' Perception of Students' Acquisition of Communication Skills}

The lecturers surveyed believe that primary teachers in training do not acquire communication skills satisfactorily. The overall mean response is 2.6 and the mode and median -2 . These findings confirm the higher frequency and percentage $(50.9 \%)$ of response 2 on the Likert scale for questions relating to the acquisition of the different communication sub-skills. 3 different sub-groups of skills can be discerned based on the descriptive data calculations. Firstly, the skills that lecturers believe are acquired the least are those as a meeting attendee and a tutor, with a mean of 2.4 in both cases and a mode and median of 2 , the same as the overall mode and median. The tutor's subskill has the greatest data spread (variance $=0.7$ ), although the difference is very small. In the middle are skills as a speaker, with results exactly the same as the overall scores: a mean of 2.6 and a mode and median of 2 . Even the variance and standard deviation are the same as the overall results. Finally, the scores for skills as a listener and communicator in the classroom are higher than the overall average, with means of 2.9 and 2.6 respectively and modes and medians of 3, again higher than the overall mode and median. The difference in this sub-group is in the way in which the data are grouped together, as there is a greater data spread for the first sub-skill (variance $=0.9$ ) than for the second one (variance $=0.4$ ). 
Table 6

Students' Degree of Acquisition of Communication Skills

\begin{tabular}{|c|c|c|c|c|c|c|c|c|c|c|c|c|c|c|}
\hline \multirow[b]{2}{*}{ Value/role } & \multicolumn{2}{|c|}{$\begin{array}{c}\text { Nothing } \\
(1)\end{array}$} & \multicolumn{2}{|c|}{$\begin{array}{c}\text { Little } \\
(2)\end{array}$} & \multicolumn{2}{|c|}{$\begin{array}{c}\text { Normal } \\
(3)\end{array}$} & \multicolumn{2}{|c|}{$\begin{array}{l}\text { Quite } \\
(4)\end{array}$} & \multicolumn{2}{|c|}{$\begin{array}{c}\text { Always } \\
(5)\end{array}$} & \multirow[b]{2}{*}{$\frac{8}{8}$} & \multirow[b]{2}{*}{ 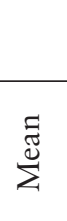 } & \multirow[b]{2}{*}{ 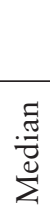 } & \multirow[b]{2}{*}{ 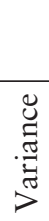 } \\
\hline & $\mathrm{n}$ & $\%$ & $\mathrm{n}$ & $\%$ & $\mathrm{n}$ & $\%$ & $\mathrm{n}$ & $\%$ & $\mathrm{n}$ & $\%$ & & & & \\
\hline Speaker & 10 & 6.6 & 72 & 47.4 & 50 & 32.9 & 14 & 9.2 & 6 & 3.9 & 2 & 2.6 & 2 & 0.6 \\
\hline Listener & 6 & 3.9 & 48 & 31.6 & 64 & 42.1 & 24 & 15.8 & 10 & 6.6 & 3 & 2.9 & 3 & 0.9 \\
\hline Teacher & 8 & 5.3 & 58 & 38.2 & 74 & 48.7 & 4 & 2.6 & 8 & 5.3 & 3 & 2.7 & 3 & 0.4 \\
\hline Attender & 16 & 10.5 & 76 & 50 & 52 & 34.2 & 4 & 2.6 & 4 & 2.6 & 2 & 2.4 & 2 & 0.5 \\
\hline Tutor & 22 & 14.5 & 64 & 42.1 & 50 & 32.9 & 16 & 10.5 & 0 & 0 & 2 & 2.4 & 2 & 0.7 \\
\hline Mean & 12.4 & 8.2 & 63.6 & 50.9 & 58 & 38.2 & 12.4 & 8.2 & 5.6 & 3.7 & 2 & 2.6 & 2 & 0.6 \\
\hline
\end{tabular}

The cross-tabulation that seems to be most significant is between lecturers' views of the importance of communication skills for trainee primary and pre-primary teachers and their perceived level of acquisition of those skills by the students. Table 7 shows that there is a greater range in the perceived level of acquisition, with 4 different responses (ranging from none to quite a lot) while the perceived importance obviously still ranges between not very and quite. $66.7 \%$ of the lecturers say that their students do not acquire communication skills satisfactorily while $20 \%$ believe that their acquisition is satisfactory or good.

As Table 7 shows, there are no significant differences between the lecturers who gave the importance of communication skills a score of 2, 3 or 4 . However, there is a significant difference between the lecturers who gave it the lowest score and those who gave it the highest one as the former feel that their students do not acquire the skills at all $13.3 \%$ of the respondents while the latter believe that $3.3 \%$ of the respondents become highly skilled (Table 7).

Table 7

Variable Cross Tabulation: Acquisition of Communication Skills and Importance of Communication

\begin{tabular}{|c|c|c|c|c|c|c|}
\hline \multirow{2}{*}{$\begin{array}{l}\text { Adquisition } \\
\text { Importance }\end{array}$} & & \multicolumn{4}{|c|}{ Level of achievement } & \multirow{2}{*}{ Total } \\
\hline & & 1 & 2 & 3 & 4 & \\
\hline \multirow{2}{*}{2} & $\%$ within $V_{2}$ & $20 \%$ & $60 \%$ & $20 \%$ & $0 \%$ & \\
\hline & $\%$ of total ${ }^{2}$ & $3.3 \%$ & $10 \%$ & $3.3 \%$ & $0 \%$ & $16.7 \%$ \\
\hline \multirow{2}{*}{3} & $\%$ within $V_{2}$ & $0 \%$ & $80 \%$ & $20 \%$ & $0 \%$ & \\
\hline & $\%$ ofl total ${ }^{2}$ & $0 \%$ & $13,3 \%$ & $3,3 \%$ & $0 \%$ & $16.7 \%$ \\
\hline \multirow{2}{*}{4} & $\%$ within $V_{2}$ & $15 \%$ & $65 \%$ & $15 \%$ & $5 \%$ & \\
\hline & $\%$ of total ${ }^{2}$ & $10.3 \%$ & $43.3 \%$ & $10 \%$ & $3.3 \%$ & $66.7 \%$ \\
\hline Total & $\%$ within $\mathrm{V}_{2}$ & $13.3 \%$ & $66.7 \%$ & $16.7 \%$ & $3.3 \%$ & $100 \%$ \\
\hline
\end{tabular}

\section{Discussion}

Table 8 provides a summary of the conclusions outlined above and reflects the need to tackle the mostly poor results by designing training activities aimed at both students and lecturers on the teacher training course. 
Table 8

Summary of Findings on Communication Skills Assessed

\begin{tabular}{lccccccccc}
\hline \multirow{2}{*}{$\begin{array}{l}\text { Variable } \\
\text { dimension }\end{array}$} & \multicolumn{3}{c}{ 1. Need to work } & \multicolumn{3}{c}{ 2. Classroom work } & \multicolumn{3}{c}{ 3. Level of achievement } \\
\cline { 2 - 10 } & $\begin{array}{c}\text { Mode/ } \\
\text { median }\end{array}$ & Mean Variance & $\begin{array}{c}\text { Mode/ } \\
\text { median }\end{array}$ & Mean Variance & $\begin{array}{c}\text { Mode/ } \\
\text { median }\end{array}$ & Mean Variance \\
\hline Speaker & 5 & 4.7 & 0.6 & 3 & 3.1 & 0.4 & 2 & 2.6 & 0.6 \\
\hline Listener & 5 & 4.6 & 0.5 & 3 & 3.2 & 0.7 & 3 & 2.9 & 0.9 \\
\hline Teacher & 5 & 4.6 & 0.7 & 3 & 3.1 & 0.9 & 3 & 2.7 & 0.4 \\
\hline Meeting attendee & 5 & 4.5 & 0.4 & 3 & 2.9 & 0.8 & 2 & 2.4 & 0.5 \\
\hline Tutor & 5 & 4.6 & 0.6 & 3 & 2.7 & 1.2 & 2 & 2.4 & 0.7 \\
\hline Mean & 5 & 4.65 & 0.5 & 3 & 3 & 0.8 & 2 & 2.6 & 0.6 \\
\hline
\end{tabular}

Based on the perceptions of lecturers, this study has determined the degree of acquisition of communication skills worked on in class by trainee primary teachers and how important this type of training should be.

Almost all of the lecturers surveyed believe that communication skills are an essential part of the initial training of primary teachers. Their responses to the survey's first question about the importance of these skills show that they believe that communication skills are of the utmost importance in primary teacher training. The lecturers almost unanimously give the highest scores for the importance of each of the different communication sub-skills. These findings are consistent with those of other studies which confirm the importance of skills training in higher education (Elmore, 2003; García San Pedro, 2007; Irigoyen, Jiménez, \& Acuña, 2011; Moreno, 2009; Valladares, 2011), specifically in primary teacher training courses (Abbott \& Huddleston, 2000; ANECA, 2004, 2006; Cruzata \& Salazar, 2012; European Commission/EACEA (Education, Audiovisual and Culture Executive Agency)/Eurydice, 2012; Fullan, 2007; Ortiz, 2005; Perrenoud, 2007; Rubio, 2009; Sanz, 2005; Tejada, 2009).

Overall, the lecturers surveyed believe that communication skills are worked on sufficiently. They tend to admit that more emphasis is placed on developing skills as a speaker (middle to high score) than on developing communication skills as a tutor (middle to low score). According to the studies reviewed, working on communication skills during initial teacher training is not just useful but necessary (Núñez \& Del Moral, 2010). However, as this study shows, systematic training is not guaranteed and much of it is left to improvisation, defined by (Huguette $\&$ Pourtois, 2006) as implicit training.

Despite this, the lecturers surveyed believe that the communication skills acquired by student teachers are unsatisfactory. This is especially true of the sub-skills for taking part in meetings, followed by sub-skills as a speaker and a tutor (low to middle score). Only skills as a listener and communicator in the classroom were given scores closer to 3 on the Likert scale. Although there are no studies that focus specifically on this point, there are a number of general studies that reveal the lack of connection between what students learn in their initial training and the skills they need in their professional lives, as a failing in advanced training (Fernández, 2009). Furthermore, a complementary study has found that even the trainee teachers themselves believe that they do not have the communication skills they need for their future professional lives (Domingo, Gallego, García, \& Rodríguez, 2010).

The contingency analyses reveal a significant drop in the scores assigned to the two previous points (from 3 to 2 ). In other words, while $53.3 \%$ of the respondents believe 
that communication skills are worked on sufficiently, $80 \%$ - believe that these skills are not acquired. This finding needs to be analysed carefully, especially given that $95.2 \%$ of the lecturers surveyed believe that communication skills are important for teachers. Table 8 shows that, although working on communication skills is deemed essential for primary teacher training, it is done only satisfactorily in each of the subjects taught. In fact, the students do not learn the skills as well as they should. This suggests that there should be more explicit work on communication skills in all of the classes taken by trainee teachers and that lecturers should be more concerned about developing their students' ability to communicate.

It is not enough to highlight the need to develop students' communication skills, given the lecturers' lack of satisfaction with the way in which they are worked on in the classroom and their perception that students do not acquire these skills satisfactorily. It may be necessary to provide training to lecturers on primary teacher training courses, teaching them the techniques and strategies required to develop their students' communication skills. These techniques could then be incorporated into their syllabuses and teaching plans (Cascante, 2004), as per the recommendations of the studies reviewed here, and tried and tested in the teaching practice of the degree, as per other studies. There are some suggested training techniques in the bibliography (Ortiz, 2005; García San Pedro, 2007; Calzada, 2007; Rodríguez Ruiz, 2011), for different geographical contexts, due to the concern about the communicational competency development of the teachers of various educational levels, as emphasised above. New training activities could be designed basing on the shortcomings detected in this study.

\section{References}

Abbott, I., \& Huddleston, P. (2000). Standards, competence and knowledge: Initial teacher training and business. International Journal of Value-Based Management, 13(3), 215-227.

ANECA (Agencia Nacional de Evaluación de la Calidad [National Agency for Quality Assessment]) (2004). La adecuación de las titulaciones de maestro al Espacio Europeo de Educación Superior [The adaptation of teaching degrees to the European higher education]. Retrieved January 20, 2012, from http://www.aneca.es

ANECA (Agencia Nacional de Evaluación de la Calidad [National Agency for Quality Assessment]) (2006). Libro Blanco. Título de Grado en Magisterio [White Paper. Degree in Teaching]. Retrieved January 20, 2012, from http://www.aneca.es/ modal_eval/docs/libroblancojun05 magisterio1.pdf

Barrón, A. (1989). Presupuestos para un programa racional de formación del enseñante [Budgets for rational teacher training programmes]. Bordón [Bordón], 41(4), 681689.

Bolívar, A., \& Domingo, J. (2004). Competencias profesionales y crisis de identidad en el profesorado de secundaria en España [Professional competencies and identity crisis among secondary school teachers in Spain]. Perspectiva Educacional [Journal of Educational Perspective], 44(2), 109-128.

Calzada, J. P. (2007). Modelo didáctico para la formación de la competencia comunicativa de dirección del proceso pedagógico en la formación inicial del profesor [Didactic model for the formation of communicative competence for educational 
process management in initial teacher training]. Revista Pedagogía Universitaria [Journal of University Teaching], 1(12), 81-97.

Camacho, S., Martínez, F., \& Mendías, A.M. (1999). La comunicación en las organizaciones educativas [Communication in educational organisations]. In M. Lorenzo, J. A. Ortega \& E. Corchón (Eds.), Enfoques comparados en organización y dirección de instituciones educativas [Comparative approaches in the organisation and management of educational institutions]. Granada: GEU.

Camacho, S., \& Sáenz, O. (2000). Técnicas de comunicación eficaz para profesores y formadores [Effective communication techniques for teachers and trainers]. Alicante: Marfil.

Cascante, C. (2004). La reforma de los planes de estudio. Un análisis político de los discursos sobre formación inicial de los profesionales de la educación [Reforming the curricula. A political analysis of discours on initial training of education professionals]. Revista interuniversitaria de formación del profesorado [Inter-university Teacher Training Journal], 18(3), 145-167.

Castellá, J. M., Comelles, S., Cross, A., \& Vilà, M. (2007). Entender(se) en clase. Las estrategias comunicativas de los docentes bien valorados [Understanding in the classroom. Communication strategies for highly rated teachers]. Barcelona: Graó.

Cea, M. A. (2002). Análisis multivariable: teoría y práctica en la investigación social [Multivariate analysis: Theory and practice in social research]. Madrid: Síntesis.

Cohen, L., \& Manion, L. (2002). Métodos de investigación educativa [Educational research methods]. Madrid: La Muralla.

Cruzata-Guzmán, R., \& Salazar-Salazar, M. (2012). La competencia comunicativa del maestro de la Educación Primaria [Communicative competence of primary school teachers]. Ciencias Holguín [Sciences Holguin], 18(1), 1-12.

Domingo, J., Gallego, J. L., García, I., \& Rodríguez, A. (2010). Competencias comunicativas de maestros en formación [Communication skills of pre-service teachers]. Profesorado. Revista de currículum y formación del profesorado [Faculty. Journal of Curriculum and Teacher Training], 14(2), 303-323.

Elmore, R. (2003). Salvar la brecha entre estándares y resultados. El imperativo para el desarrollo profesional en educación [Bridging the gap between standards and results. The imperative for professional development in education]. Profesorado. Revista de currículum y formación del profesorado [Faculty. Journal of Curriculum and Teacher Training], 7(2), 9-48.

European Commission/EACEA (Education, Audiovisual and Culture Executive Agency)/ Eurydice. (2012). Developing key competences at school in Europe: Challenges and opportunities for policy. Luxembourg: Publications Office of the European Union.

Fernández, E. (2009). El discurso de la formación basada en competencias profesionales. Un análisis crítico de la formación inicial de profesionales en la Educación Superior [Speech training based on professional skills. A critical analysis of the initial training of professionals in higher education]. Revista Electrónica Interuniversitaria de Formación del Profesorado [Inter-university Electronic Journal of Teacher Education], 12(1), 151-160.

Fox, D. J. (1987). El proceso de investigación en educación [The research process in education]. Pamplona: EUNSA. 
Fullan, M. (2007). El cambio educativo con creces [More than educational change]. Madrid: Akal.

García San Pedro, M. J. (2007). Realidad y perspectivas de la formación por competencias en la Universidad [Reality and prospects for skills training in universities] (Unpublished doctoral dissertation). Autonomous University of Barcelona, Barcelona, Spain.

Huguette, D., \& Pourtois, J. P. (2006). La educación implícita [Implicit education]. Madrid: Editorial Popular.

Irigoyen, J. J., Jiménez, M. Y., \& Acuña, K. F. (2011). Competencia y educación superior [Competition and higher education]. REMIE [REMIE], 16(48), 243-266.

McMillan, J., \& Schumacher, S. (2005). Investigación educativa: una introducción conceptual [Educational research: A conceptual introduction]. Madrid: Pearson.

Kaplún, M. (2004). A la educación por la comunicación [Education by communication]. Quito: CIEPAL (Centro Internacional de Estudios Superiores para América Latina) [International Centre of Superior Studies for Latin America].

Moreno, T. (2009). Competencias en educación superior [Higher eductation competencies]. Perfiles [Profiles], 31(124), 69-92.

Núñez, M. P., \& Del Moral, C. (2010). Competencia léxica y competencia comunicativa: bases para el diseño de programas didácticos en la educación escolar [Lexical competence and communicative competence: Basis for the design of educational programmes in classroom education]. Lenguaje y Textos [Journal Language and Texts], 23, 91-97.

Ortiz, E. (2005). Comunicarse y aprender en el aula universitaria [Communicate and learn in the university]. La Habana: Holguín.

Perrenoud, P. (2007). Desarrollar la práctica reflexiva en el oficio de enseñar [Developing the practice of reflection in teaching]. Barcelona: Graó.

Rodríguez Ruiz, N. (2011). Modelo pedagógico para la formación de la competencia comunicativa [Pedagogical model for the formation of communicative competence]. Cuadernos de Educación y Desarrollo [Journal of Education and Development], $3(2), 1-14$.

Rubio, M. (2009). El desarrollo de la competencia comunicativa intercultural en la formación inicial [The development of intercultural communicative competence in pre-service teachers]. Estudios Pedagógicos [Journal of Educational Studies], 35(1), 273-286.

Sánchez Carrión, J. J. (1989). Análisis de tablas de contingencia: el uso de los porcentajes en las Ciencias Sociales [Analysis of contingency tables: The use of percentages in social sciences]. Madrid: Centro de Investigaciones Sociológicas.

Sánchez Cerezo, S. (Ed.) (1991). Tecnología de la Educación [Education technology]. Madrid: Santillana.

Sanz, G. (2005). Comunicación efectiva en el aula. Técnicas de expresión oral para docentes [Effective communication in the classroom. Oral speaking techniques for teachers]. Barcelona: Graó.

Schutt, R. K. (2001). Investigating the social world: The process and practice of research. Thousand Oaks: Sage.

Tagliacarne, G. (1968). Técnica y práctica de las investigaciones de mercado [Techniques and practice in market research]. Barcelona: Ariel. 
Tejada, J. (2009). Competencias docentes [Teaching skills]. Profesorado. Revista de currículum y formación del profesorado [Faculty. Journal of Curriculum and Teacher Training], 13(2), 1-15.

Valladares, L. (2011). Las competencias en la educación científica. Tensiones desde el pragmatismo epistemológico [Competencies in science education. Tensions from epistemological pragmatism]. Perfiles [Profiles], 33(132), 158-182.

Correspondence concerning this paper should be addressed to Antonio Rodríguez Fuentes, PhD, Faculty of Education, University of Granada, Spain, Campus of Cartuja, s/n, 18071, Granada, Spain. Email: arfuente@ugr.es 